Historic, archived document

Do not assume content reflects current scientific knowledge, policies, or practices. 



\section{SPECIAL PRICE LIST}

\section{(1) \\ SEEDS,STOCKS, BULBS,L}

FOR SALE BI

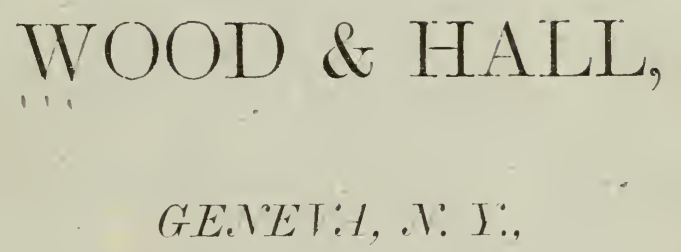

IMPORTERS ANI DEALERS IN ALI, KINDS OF

NURSERY STOCK, SEEDS, BULBS. ANI

HORTICULTURAL GOODS.

GENETA, I. Y.:

PRINTED BY S. H. PARKER, GAZETTE OFFICE. 1871. 
In consequence of the pressure of our Seed Trade we have been unable at this season to prepare as usual our General Price List of Nursery Stock. Our customers, however, may rest assured that we have still the most abundant facilities for furnishing in quantities, and at lowest market rates, the choicest quality of

Standard and Dwarf Fruit Trees,

Grape Vines, Rasplerries, Blackberries, Strawberies, Gooseberries, Rhubarb,

Hedge Plants, Deciduous and Evergreen Trees, Weeping Trees, Shrubs, Paonies, Roses, Bedding Plants, Green-House Plants, de.

Our lists embrace nearly all the Nurseries in every State in the Union, hence you are most sure to get what you want if it can be found anywhere, and of obtaining it at the lowest market rate. Let us know what you want, whether it is one item or a general assortment of stock, and we shall be happy to give you the best rate which the market affords.

Give us a call before purclasing.

We would invite special attention to our facilities for supplying, in large or small quantities,

LABELS, of all kinds, for Nursery use; also,

LABEL WIRE,

BASS BARK, for budding and tying, \&c.

For prices, consult Miscellaneous Articles, page 7 and 8. 


\section{STOCKS.}

Per 1000

Apple Stocks, 2 years, rery fine.................... $\$ 1200$

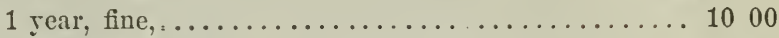

1 year, Yo. 2, good,..................... 700

Cherry Stocks, MLazzard, 1 year,................. 1000

Pear Stocks, 1 year, No. 1, very fine,................. 2000

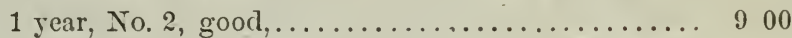

Plum Stocks, 1 year, very scarce, per $100, \ldots \ldots \ldots \ldots \ldots \ldots 00$

Quince Stocks, Argers, extra selected,................ 25 00

No. 1 Lajers, fine,................ 1800

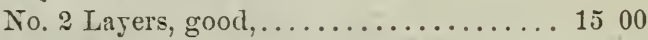

Rose Stocks, Maxetti, .......................... 00

Willow Stocks, Conewelt, per $100, \ldots \ldots \ldots \ldots \ldots$....... 00

\section{OUTTINGS.}

Orange quince Cuttings.......................\$ 00

Angers Quince Cuttings,....................... 400

Comewell Willow Cuttings,...................... 500

0sier Willow Cuttings, long, for tying,.............. 400

66 for planting,................ 200

Silver Poplar Cuttings, ...................... 5 00

Weeping Willow Cuttings, ................... j 00

\section{BULBS.}

Allinm Molle,

Per 100 Imaryllis Longifolia, $\$ 1000$

*n new sorts,

Anemones, double and single..................... 500

Crocus, namer.............................. 200 
Crocus, mixed, $\ldots \ldots \ldots \ldots \ldots \ldots \ldots \ldots \ldots \ldots \ldots \ldots \ldots \ldots \ldots \ldots \ldots \ldots, \$ 150$

Colchicum, ........................... 800

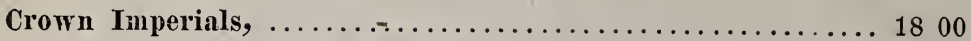

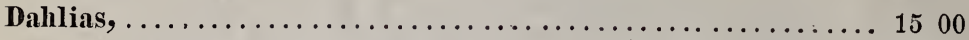

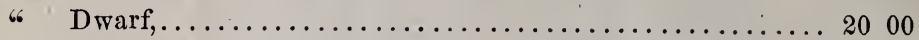

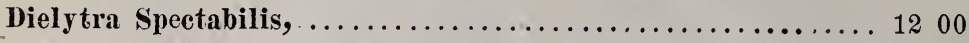

Gladiolus, Hybrids, named, ................... 800

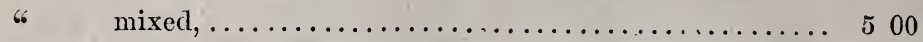

Hyacinths, double and single, named,.............. 1000



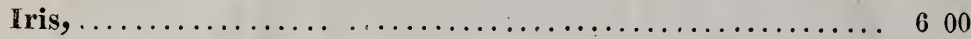

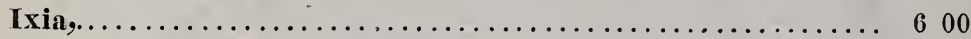

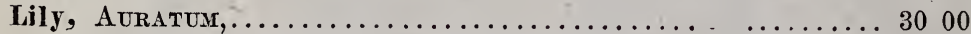

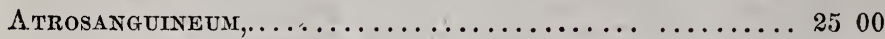

Aurantiacum, .........................20 00

Brownir,.....................\$3 00 each.

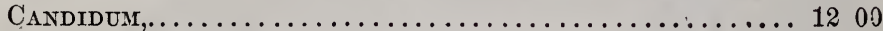

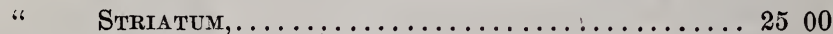

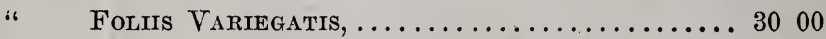



Excelsum, .......................... 5000

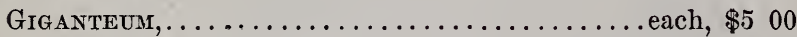



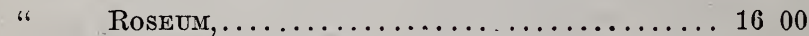

" RUBRUM,......................... 1600

" Punctatum, ....................60 600

" Metpomene,....................60 60

" Monstrosum Album, Roseum Rubrum,....... 6000

LONGIFLORUM,........................ 1200

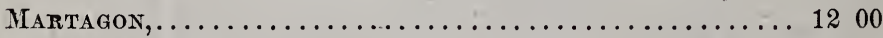

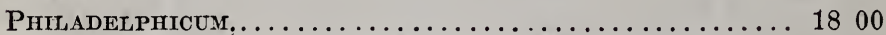

Superbum, .......................... 1800

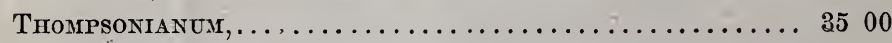

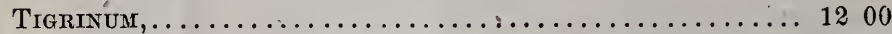

Takesima,...........................660 00

Lily-of-the-Valley, ......................... 500

Kadeira Vine............................. 400

Narcissus Polyanthus,....... .................. 1000

6 Double and Single,.................... 500

" JoNQurLs, ............................ 400

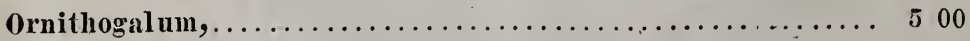




Ponoules, Ciriscate, ...

Ranunculus,............................. 300

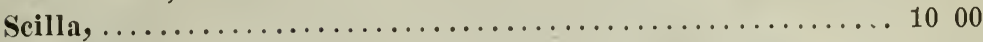

Snow-Drops, ............................... 500

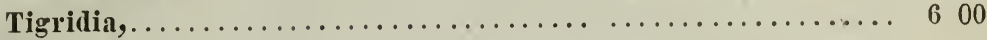

Tritoma,......................\$3 00 per doz.

Tuberoses, Dotble Italirax, strong bulbs, .............. 600

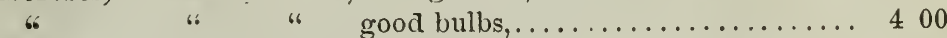

Tulips, named............................. 300

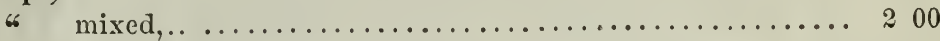

\section{SEIDS.}

A per pound

Arbor-Vitæ, American, ...................... \$5 00

66. Chinese,.......................... 400

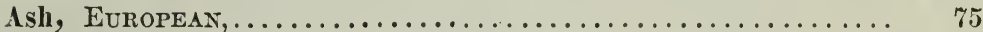



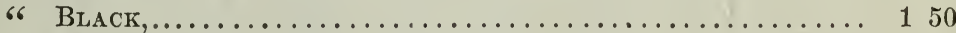

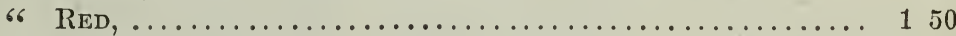

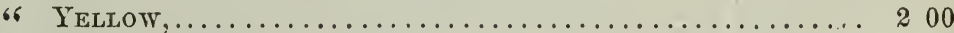





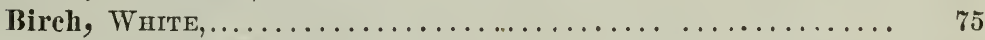

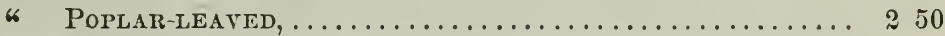

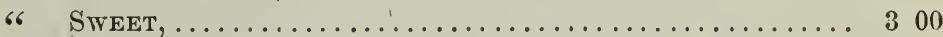

Buckthorn, for Hedges,...................... 200

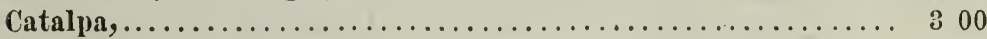

Cherry, BrRd,............................ 300

Clematis, (VIrgix's Bower) ..................... 300

Cypress, Deciduous,......................... 250

6 LAwsox's,$\ldots \ldots \ldots \ldots \ldots \ldots \ldots$ per oz., $\$ 125$

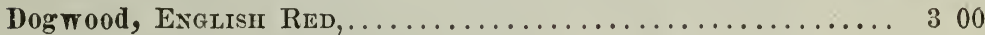

66 BLUE, ............................ 300

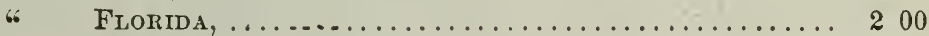

6 Cornelian Cherry,................... 200

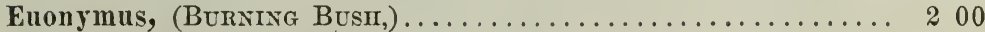



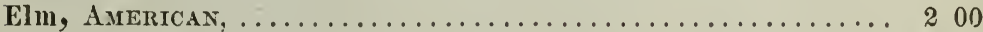

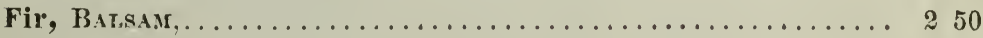


Fir, Europeax Silver,

Hawthorn, for Hedges,.

Halesia, (Silven Bell,)

Hickory, Sirell B.rrk,

Honey Locust, for Hedges, .

Horse Chestuut, coinmon,

Jnniper, Common,

$\$ 200$ per bushel.

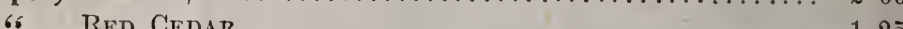

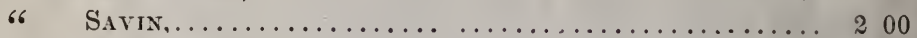

Kentucky Coffee Tree,........................ 200

Kolreuteria,............................ 400

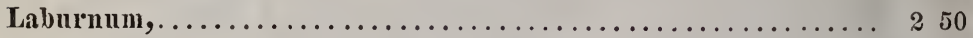

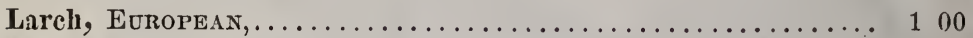

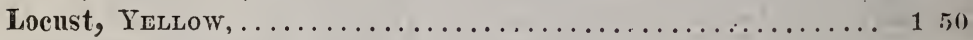



Lilac, Purpte.............................. 400

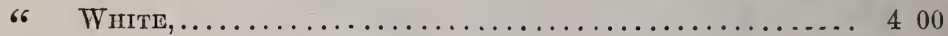

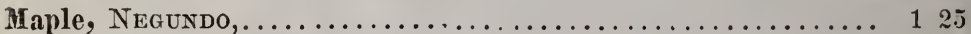

66 Negundo, folits $\Lambda$ Rgenteis. ........\$1 50 per oz.

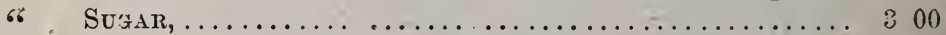



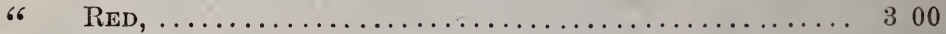

Magnolia Acuminata,. ....................... 250

66 GrandifLORA,..................... 300

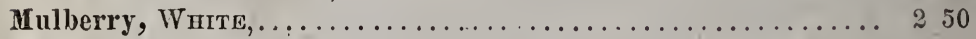

Osage Orange,............................... 100

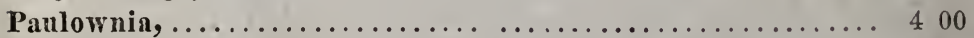



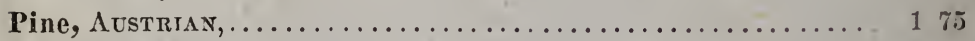

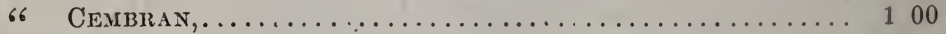

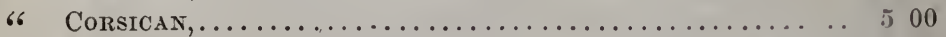

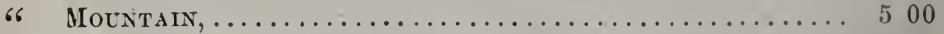

66 Prтcr, ............................ 600

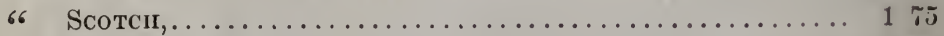

6 SEASIDE, ............................ $150 \ldots$

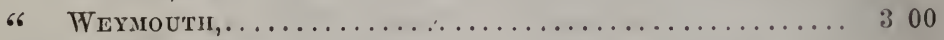

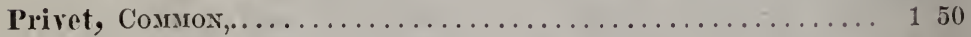

6 JaPANESE, ........................ 200

Salisburia,............................. 100 nuts, $\$ 300$

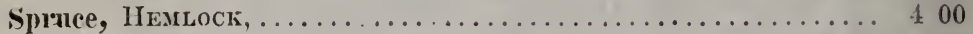

66 Norwar,$\ldots \ldots \ldots \ldots \ldots \ldots \ldots \ldots \ldots \ldots$ lbs. for $\$ 600 \quad 75$

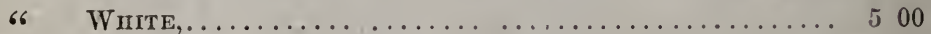

Thorn, Evergreen, ........................ 300

Tulip Tree,............................ 200 
Seeds not named above will be supplied at lowest murket rates, as far an they can be obtained.

PRIME FRESH APPLE SEED,

$\$ 800$ per bushel.

10 bushels for ş5.j 00

BEST FRENCII PEAR SEEI,

$\$ 200$ per pound.

\section{MISCELTANEOUS ARTIOLES.}

In connection witl our extended and increasing trado in Nursery stock of all kinds, we have made arrangements to supply our customers with many articles and conveniences constantly needed by Nurserymen. Our location and experience enables us to select the best and most approved kinds that can be had of the various items, and our aim is in crery case to furnish nothing but the best that can be hald to meet the wants of our patron-. Full descriptions of any of the following articles will be cheerfully given to any desiring to purchase, and for anything not named we shall he grlat to give prices on application.

Bass Bark, for budding and tying,... per lls, 30 cents, 100 llss. for \$ 2000 Barometers, ................ each, \$s.j 00 to $\$ 3000$.

Berry Baskets, best style,......... p

Market Crates to hold 60 pint baskets,....... $\$ 250 ; 60$ quirt haskets, \$2: i.j.

Bouquet Papers,............. per 100, $\$ 200$ to $\$ s 00$.

Bouquet Holders,.............. 30 cents to 8500 .

Budding Knives, to open and shut, . . each, $\$ 100$ to $\$ 300:$ per duz. $\$ \$ 00$. " " fast handles,....... each, 25 to 50 cents.

Compound Gishurst,........... 1 1h, hoxes, erch. $\$ 100$.

Compound, Sheldon's Improred, a sure remedy for Grubs, Slugs, Borers, Canker. Worms, and all Insect Pests, and a raluable Fertilizer for Trees, Plants, Vines, etc., Dilute with three

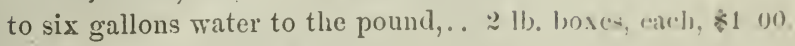
Crocus Pots, plain and fancy in assortment. Grafting Wax,$\ldots \ldots \ldots \ldots \ldots \ldots \ldots$ per $11, .30$ cents, 


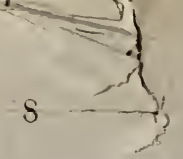

Grafting Knives, to open and shut,.... each, $\$ 100$, per doz. $\$ 800$.

" " fast handles,....... each, 30 cents.

Grafting Paper,............. per ream, $\$ 400$.

Green House Rods, two feet long,.... 50 cts. per doz.; per 1000, $\$ 800$.

Other lengths in

proportion.

Green House Pump and Sprinkler,

Page's Patent,............... each, $\$ 500$ to $\$ 1000$.

Hand Glass Frames for $12 \times 14$ glass,... cach, 50 cents.

Hyacinth Glasses, colors,......... per doz., $\$ 300$ to $\$ 900$.

Jersey Peat, for Azalcas, \&c.,....... per barrel, \$2 50 .

Labels, Trec, best quality, printed,.... per $20,000,43$ cts. ; per 1000, 45 cts.

6. " " $\quad$ plain, notched, per $20,000,38 \mathrm{cts}$; per $1000,40 \mathrm{cts}$.

" " pierced,............ per 20,000,40 cts.; per $1000,45 \mathrm{cts}$.

"Plant or Pot,........... per 10,000, 50 cts. ; per 1000,65 cts.

" Package, $1 \frac{8}{4} \times 6$ inches,....... per 1000, $\$ 125$.

" Bale, $2 \times 12$ inches,.......... per 1000, $\$ 800$.

Label Wire, copper,........... per pound, 55 cents.

" iron, annealed,....... per pound, 30 cents.

Lawn Mower, Excelsior, cuts 14 to 30 inches wide..$\ldots \ldots \ldots \ldots \ldots \ldots$ each, $\$ 2500$ to $\$ 12500$.

Oiled Paper, for sending samples,

sheets $24 \times 36$ inches, . . ........ each, 6 cents ; per $100, \$ 500$.

Order Books for Agents,....................each 75 cents.

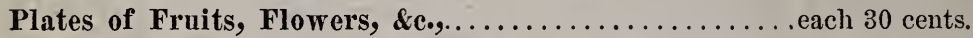

Special prices for large quantities.

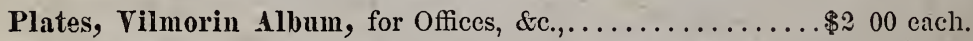

Packing Moss, ................ per barrel, $\$ 250$.

Pencils, marking,................ per dozen, $\$ 100$.

Pot Fences,.................. 25 cents to $\$ 100$ each.

Pruning Knives, to epen and shut,...... each, $\$ 1$ to $\$ 300$.

" "fast handless,........ 40 cents each.

Pruning Shears,.............. each, $\$ 125$.

Rustic Seats, Brackets, Vases, Hanging Baskets, ètc., all styles and prices.

Stakes for Dahlias, ete., 12 inches long,.. per 1000, $\$ 400$; per doz., 25 cts.

Sand, White Propagating,.......... per barrel, $\$ 250$.

Tin Foil,................. per pound, $\%$ cents.

Tools, Horticultural, of every description.

Thermometers,................ cach, 50 cents to $\$ 500$.

Trellis, Pot, Plant or Garden, all styles, sizes and prices.

Whale Oil Soap, ............... per lb., 25 cents; $1001 \mathrm{~b}$. kegs, $\$ 10$.

Window Boxes, Encaustic Tile,........ cach, $\$ 1500$ to $\$ 3000$.

Wire Baskets, all styles and prices.

Vases, Garden Statuary, all sţ̄es and prices. 